\title{
High Speed 3-Dimensional Measurement by Shape from Focus Method Using Segmental Focal Images
}

\author{
Susumu Shibata Non-member (Mu-Skynet Ltd.) \\ Tomoyasu Saigo Non-member (Mu-Skynet Ltd.) \\ Masashi Hayashi Non-member (Mu-Skynet Ltd.) \\ Ryo Taguchi Non-member (Nagoya Institute of Technology) \\ Taizo Umezaki Member (Nagoya Institute of Technology)
}

Keywords : Shape from focus, 3-dimensional measurement, Segmental focal image

With development and diffusion of fine processing technology, the higher degree of accuracy is required for quality inspection of mechanical equipments. In particular, equipments made from assembly of semiconductor material and/or printed circuit board need a micrometer precision to measure the geometric dimension accuracy. This paper has presented the Shape from focus method using segmental focal images. The segmental focal image is defined by various focal lengths in one field of view. Furthermore, we give it a twist of analyzing frequency distribution curve to improve its efficiency.

Our approach brings an idea of the optical system into our experiment to complete two tasks at the same time; obtaining target image sequence while shifting the field of view. As result we cut loss arising from drive accordingly. A camera is not aligned perpendicularly to the image plane when the camera is pointed slightly upward from the ground level than they would. The focal length changed in accordance with shifting the field of view by moving the camera, in fact, the best focused points shifted horizontally in the direction of the field of view. (See Fig.1)

We show the experimental conditions as follows (1) we move the camera at 8 degrees vertical tilt. (2) We shot images every 180 $\mu \mathrm{m}$. (3) The field of view covers $6.3 \mathrm{~mm} \times 4.8 \mathrm{~mm}$.

To search the best focal points of the target image sequence, we compared with estimated best focal points of the frequency distribution curve, which is analyzed by defocus spectrum levels. The image in defocus is indicated as the convolution between focused images and blurring kernels. Therefore, it is defined the spectrum distance as following equation.

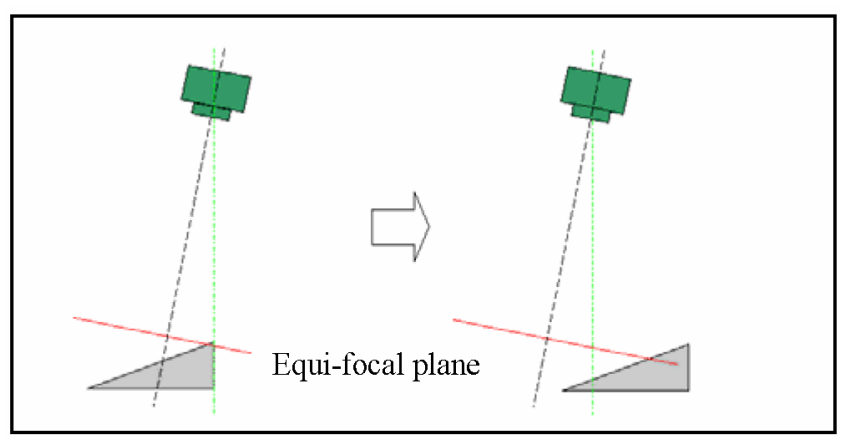

Fig. 1. Tilted camera and shifted object

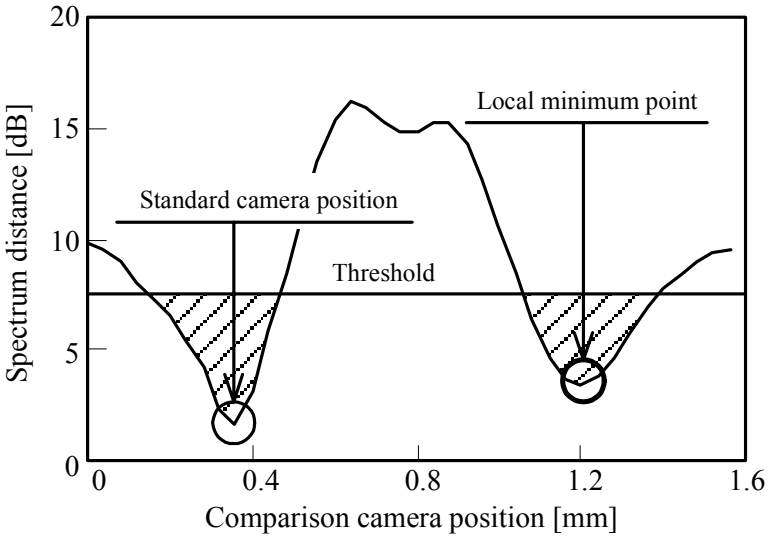

Fig. 2. Two local minimum of Spectrum distance

$$
\begin{aligned}
d\left(z_{1}, z_{2}\right) & =\left|\log F\left(z_{1}\right)-\log F\left(z_{2}\right)\right| \\
& =\left|\left(a z_{1}^{2}+b z_{1}+c\right)-\left(a z_{2}^{2}+b z_{2}+c\right)\right|
\end{aligned}
$$

where $F(z)$ is Fourier component of images, $z_{1}, z_{2}$ are working distances. Note that the blurring kernels are assumed the Gaussian form in Eq. (1). As shown in Eq. (1), a frequency distance has two local minima (show Fig. 2). One minimum is the trivial solution $\left(z_{1}=z_{2}\right)$. The second minimum shows the position, which have a similar blurring image. The position of second minimum depends on the standard camera position $\left(z_{1}\right)$. By a linear approximation of $z_{2}$ as a function of $z_{1}$ using blurring images, the focus point which corresponds to fixpoint $\left(z_{1}=z_{2}\left(z_{1}\right)\right)$, is acquired.

The experiment shows that the SFF method using the frequency comparison had been measured with high accuracy $(20 \mu \mathrm{m})$ similar to the accuracy of the SFF method using Laplacian variance. In addition, the SFF method using the frequency comparison has kept the high accuracy when the number of images is reduced. This result shows that the SFF method using the frequency comparison is able to measure the objects with the high speed and the high accuracy.

The spectrum distances have two local minima, however the spectrums distances in front of a focal point changed smaller than one in the back. One possible cause of this property is the superposition of both distortion of equi focal plane and change of working distance by tilt. Because the accuracy has been lost in the case of a small change of spectrum distances, additional experiments in different conditions are needed to find out the cause. 


\section{区分的焦点画像による合焦式高速三次元計測}

\begin{tabular}{|c|c|c|c|c|c|}
\hline 非会員 & 柴田 & 進* & 非会員 & 西郷 & 知泰* \\
\hline 非会員 & 林 & 真司* & 非会員 & 田口 & 亮** \\
\hline 員 & 每崎 & 太造** & & & \\
\hline
\end{tabular}

\section{High Speed 3-Dimensional Measurement by Shape from Focus Method Using Segmental Focal Images}

Susumu Shibata*, Non-member, Tomoyasu Saigo*, Non-member, Masashi Hayashi*, Non-member, Ryo Taguchi**, Non-member, Taizo Umezaki**, Member

This paper has presented the Shape from focus method using segmental focal images. The segmental focal image is defined by various focal lengths in one field of view. By using these images, the focal length at particular position changes in accordance with shifting the field of view. The experiment was conducted in a smooth, uninterrupted manner and allowed us a high-speed concatenated three-dimensional reconstruction. Furthermore, combining this method with frequency transfer analysis, a high-precision measurement was possible even if the shooting interval between source images were enlarged. 3-dimensional high speed measurement can be achieved by combining these two methods effectively.

キーワード : 合焦法, 三次元計測, 区分的焦点画像

Keywords : Shape from focus, 3-dimensional measurement, Segmental focal image

\section{1. はじめに}

微細加工技術の発展により部品の精密化が進むにつれ， 品質管理の上で要求される検査精度も高くなっている。全 ての生産品に対して高精度な寸法計測をおこなうことは人 間による目視判定では困難であり，自動検查の需要が高ま つている。このような背景から画像処理技術を用いた不良 品の自動検査法が研究・開発されている。しかし，工業製 品の多くは三次元形状をしており，その立体形状を計測す ることにより検査したいというニーズは多い。特に小型化 が急速に進んでいる半導体や実装用のプリント基板では，3 次元形状に対してマイクロメートル単位の計測精度が要求 されてきている。

三次元計測はコンピュータビジョンの分野でさまざまな 研究が行われている(1)。実用段階にある手法としては光切断 方式(2)，パターン光投影方式(3)(4)などの三角測量の原理に基

\footnotetext{
(有) ミュースカイネット

干466-8555 愛知県名古屋市昭和区御器所町

名古屋工業大学内 22 号館 オフィス 7

Mu-Skynet Ltd.

Office 7, $22^{\text {nd }}$ Bldg, Nagoya Institute of Technology, Gokiso-Cho,

Syouwa Ward, Nagoya Aichi 466-8555

** 名古屋工業大学大学院

T466-8555 愛知県名古屋市昭和区御器所町

Nagoya Institute of Technology

Gokiso-Cho Syouwa Ward, Nagoya Aichi 466-8555
}

づいた能動的計測法が一般的であり, 計測機器も市販され ている。しかし, 能動式計測では表面反射が強い材質に対 して精度が出しにくいという面がある。一方, 微小部品の 三次元形状を計測する手法の一つとして合焦法 (Shape from Focus 法) が提案されている ${ }^{(5)}(8)$ 。この手法は, 複数の画像 の合焦情報から表面の三次元位置を求める方法であり, 受 動的な方式ながら精度が高く, 半透明な対象にもある程度 対応できるという利点を持つ。しかしながら，データの入 力に際してカメラもしくは対象を動かす必要があるため に, データ入力時間がネックとなる。精度を上げるために はカメラの移動間隔を小さくする必要があり, 画像枚数と ともに撮影時間も増加する。ガラス平板を対象とレンズの 間に挿入しカメラを動かさずに焦点距離を変える方法も考 えられている(6)。しかしこの方法に対しても視野の移動と計 測のための停止が必要であり, 駆動による時間のロスを完 全に防ぐことはできない。また, ガラス平板群と, ガラス 平板の切替機構等の特殊な機構が必要であり, システムが 複雑となる。

本研究では, 1 視野内で複数の合焦情報を得る光学系を用 いた合焦法の開発を行う。このような光学系で得られる画 像を本研究では区分的焦点画像と呼ぶ。区分的焦点画像を 用いることで，視野の移動と計測を同時に実施することが でき，機械駆動によるロスを極力押さえることが可能とな 
る。本論文では，カメラ光軸を基準平面から傾けた位置に 配置し, 区分的焦点画像を取得する。ここで, 基準平面は, 計測対象を配置する平面であり，駆動軸と平行とする。

また，少ない撮影枚数での高精度計測に有効な周波数比 較法の適用可能性についても検討を行った。

\section{2. 合焦法による計測方法}

合焦法は，単眼カメラでレンズの合焦位置（フォーカス の合う位置）を移動させながら撮影し，撮影画像から最も よくフォーカスの合うときの画像を求め，その合焦位置よ り三次元形状を求める方法である。

焦点ずれによるぼけの生成過程は，合焦点画像とぼけの 点広がり関数 (Point Spread Function, PSF) の畳み込み積分 としてモデル化されることが知られている。

$$
i_{d}(x, y)=h(x, y) * i_{f}(x, y)
$$

$i_{d}(x, y)$ はぼけ画像, $h(x, y)$ は点広がり関数, $i_{f}(x, y)$ は合 焦点画像である。また，点広がり関数を 2 次元のガウス関

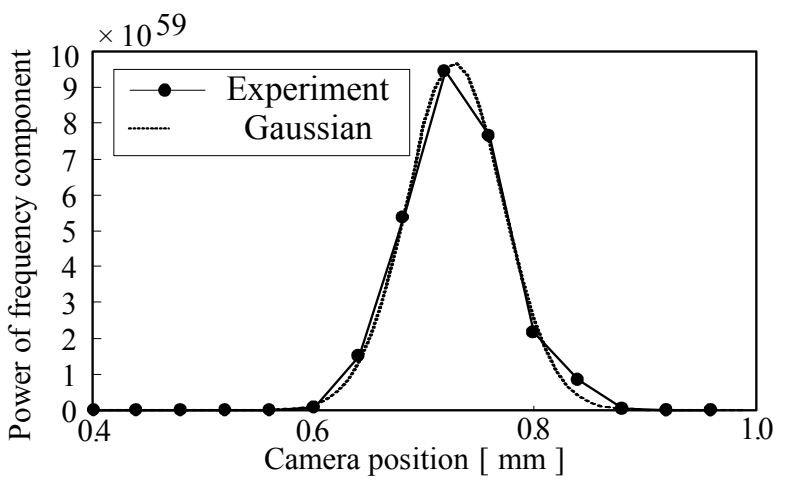

Fig. 1. Change of power of frequency component

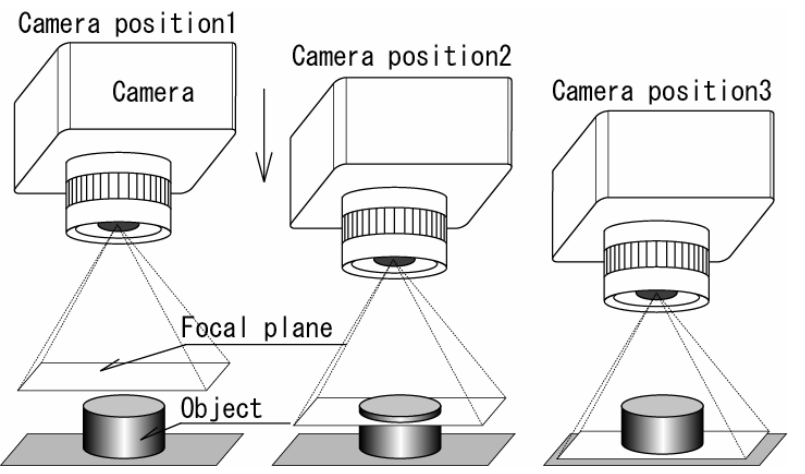

(a) Capturing image of shape from focus

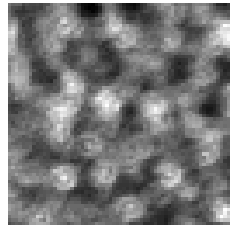

(1) Z position 1

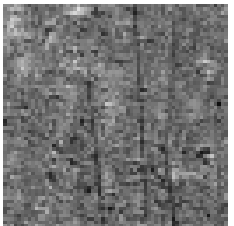

(2) $\mathrm{Z}$ position 2

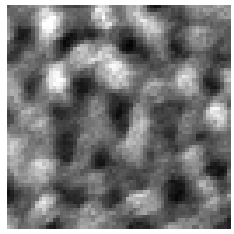

(3) $\mathrm{Z}$ position 3 (b) Captured images [local area only]

Fig. 2. Shape from focus
数として仮定すると周波数成分の増减もガウス型となる。

$$
F_{u}(z)=F_{u}(Z) \exp \left(-\frac{(z-Z)^{2}}{\sigma^{2}}\right)
$$

ここで, $F_{u}(z)$ はカメラ位置 $z$ における周波数 $u$ のパワー 值， $Z$ はガウス関数の中心 (合焦位置)， $\sigma$ はレンズの特性 により定まる定数である。実際の周波数の増減とガウス分 布との比較結果を Fig. 1 に示しており, ガウス分布がよい近 似を与えるモデルであることがわかる。

また，点広がり関数の周波数特性もガウス型となる。

$$
H(u, v)=\exp \left(-\frac{u^{2}+v^{2}}{2} \sigma_{h}^{2}\right)
$$

ここで, $(u, v)$ は空間周波数であり, $H(u, v)$ は点広がり関数 の周波数特性である。(3)式より, 焦点ずれの際に生じるぼ けを低域通過フィルタとして扱い, 微分等により高周波成 分を抽出することにより, 焦点が合う度合いを表す量（合 焦測度）を求める。画素毎に最も合焦測度の大きい位置を 探索し, 画像全体の三次元形状を計測する。合焦位置を探 索するため, 通常 Fig. 2 に示すように, カメラもしくは計測 対象を $z$ 方向に動かしながら撮影を行う。

\section{3. 区分的焦点画像の取得}

前章で示したとおり，合焦法ではカメラ位置 $z$ が変化す ることにより生じる $F_{u}(z)$ の変化から合焦位置を取得する。 しかし, 1 視野以上の範囲を計測するためには $(x, y)$ 方向の移 動機構が必要である。逆に計測中は $z$ 方向の移動のみであ り，高速計測には適していない。

本研究では，基準面に対しカメラ光軸を斜めに交差させ るようにカメラを配置する (Fig. 3)。この配置にすることで 1 枚の画像中でも $z$ を変化させることができる。計測対象を 水平方向に移動させることにより, 計測対象の同一点に対 して, 複数の $z$ での画像を得ることができる。実験では, カメラを基準面に対して約 $8^{\circ}$ 傾けており, 水平方向の移動 量について $180 \mu \mathrm{m}$ 毎に撮影を行った。撮影視野は $6.3 \mathrm{~mm}$ $\times 4.8 \mathrm{~mm}$ としている。この条件の場合， $z$ 方向の移動量は $20 \mu \mathrm{m}$ 程度であり，同一点を 35 回撮影することとなる。

Fig.4 に実際の撮影画像を示す。画面上側では合焦位置よ り $z$ が近く, 画面下側では遠くなっていることがわかる。

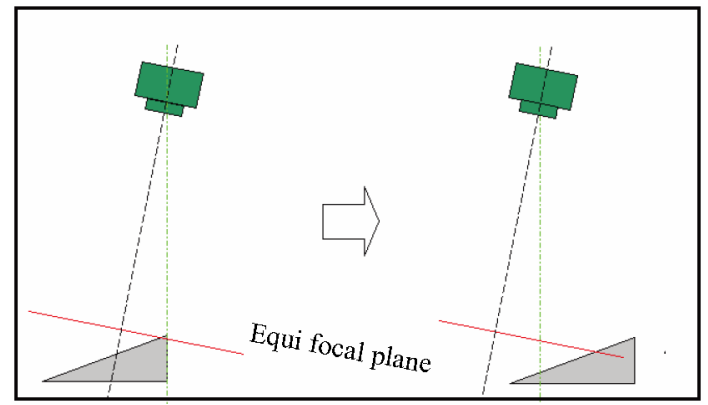

Fig. 3. Tilted camera and shifted object 


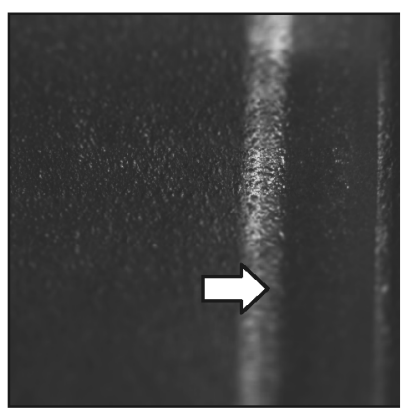

(a) $0 \mu \mathrm{m}$ shift

(z distance $0 \mu \mathrm{m}$ )

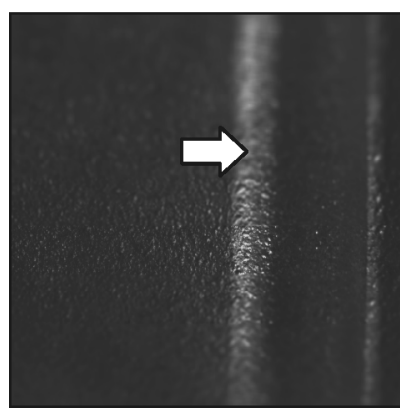

Arrows in each image shows a characteristic point to figure out the moving objects.

A arrowed point changes that focal state, i.e., defocus(a), focus (b) and defocus again(c).

(c) $3600 \mu \mathrm{m} \mathrm{shift}$ (z distance $400 \mu \mathrm{m}$ )

Fig. 4. Captured images

\section{4. 周波数比較法}

合焦法は，合焦測度の最大值を探索し，合焦位置を求め る。しかし，合焦位置近傍での撮影を複数行う必要があり， 精度向上のために被写界深度を浅くした場合，撮影を多数 回行う必要がある。ところで，2 章で示したように，ピント ぼけは合焦画像に対してぼけカーネルが作用した結果と考 えられる。ぼけ画像に対して周波数変換を施し，その変化 を評価することでぼけカーネルの変化を抽出できると考え られる。

パワースペクトル間の距離を以下の式で定義する。

$$
\begin{aligned}
d\left(z_{1}, z_{2}\right) & =\left|\log F_{u}\left(z_{1}\right)-\log F_{u}\left(z_{2}\right)\right| \\
& =\left|\left(a z_{1}^{2}+b z_{1}+c\right)-\left(a z_{2}^{2}+b z_{2}+c\right)\right|
\end{aligned}
$$

$z_{2}$ を固定し， $z_{1}$ を変数としてみなしたとき，(4)式は $z_{1}$ に対 する二次式となり, 二つの解を持つ。すなわち， $z_{1}=z_{2}$, $z_{1}=-z_{2}-b / a$ である。前者は自分自身, 後者は合焦位置を超 えた位置で最も近いボケをもった位置を示している。

周波数比較法では, 自分自身と同程度のボケを持つ位置 との対応関係から合焦位置を検出する手法である。周波数 比較による合焦位置検出のフローチャートを Fig.5 に示す。

提案する方法は, まず(1)撮影画像から計測点の局所領域 を切り出し，(2)局所領域の周波数成分を抽出する。この処 理をす心゙ての撮影画像の同一場所に対して行う。そして, ( 3 )それぞれの周波数成分を総当たりで差をとり比較する。 次に(4)一つの周波数成分を基準とした比較データの極小 值の位置を求める。最後に( 5 )極小值位置の変化から合焦位

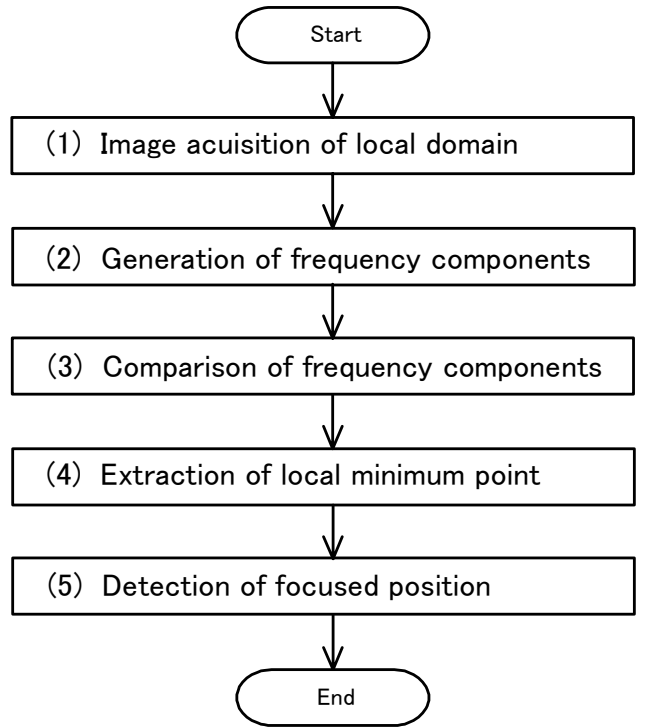

Fig. 5. Process flowchart

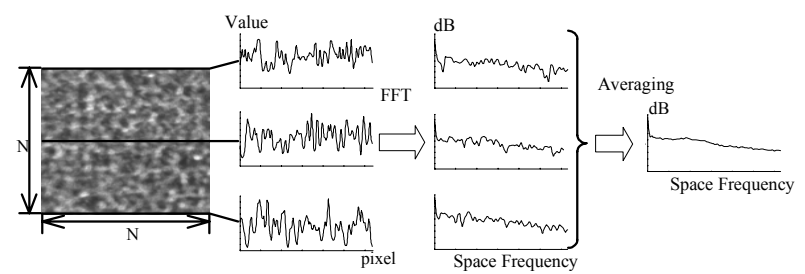
(a) Source image
(b) Brightness
(c) Power Profile
Spectrum
(d) Averaged Spectrum

Fig. 6. Process of averaged frequency calculation

置を求める。

以下に詳しい処理内容を述べる。

$\langle 4 \cdot 1\rangle$ 周波数成分の抽出画像中から計測点近傍の $\mathrm{N} \times \mathrm{N}$ [pixel] の局所領域を切り出し, フーリエ変換を行う。 ここで，Fig.4 に見るとおり区分的焦点画像では対象画像は 垂直方向でぼけ量（つまり，ぼけカーネル）が変化してい ることに注意する。このことより, 垂直方向に対しては 2 章の内容, 及び(4)式に修正が必要となる。区分的焦点画像 でも本論文の手法を適用するため, フーリエ変換は画像の 水平成分に対してのみ求めることとした。得られた水平方 向のフーリエ変換のパワースペクトルを局所領域内で平均 したデータを周波数成分とする。処理の様子を Fig. 6 に示す。

〈4-2〉周波数成分の比較 (5)式によりスペクトル 距離を求める。撮影画像に対し, 全ての組合せについて距 離の計算を行う。

$$
d\left(G_{i}, G_{j}\right)=\sqrt{\frac{1}{N} \sum_{u=1}^{N-1}\left(G_{i}(u)-G_{j}(u)\right)^{2}}
$$

ここで， $i, j$ は距離を計算する 2 枚の画像の番号, $u$ は空間 周波数, $G_{i}(u), G_{j}(u)$ はそれぞれの画像の周波数成分を示 す。 


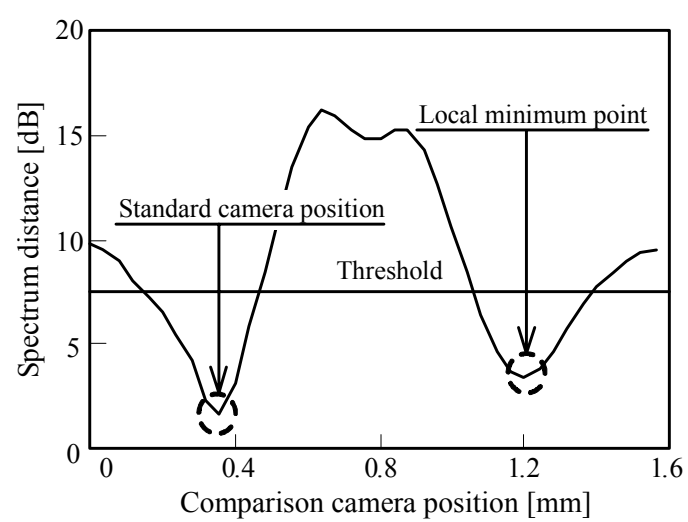

Fig. 7. Spectrum distance and local minima

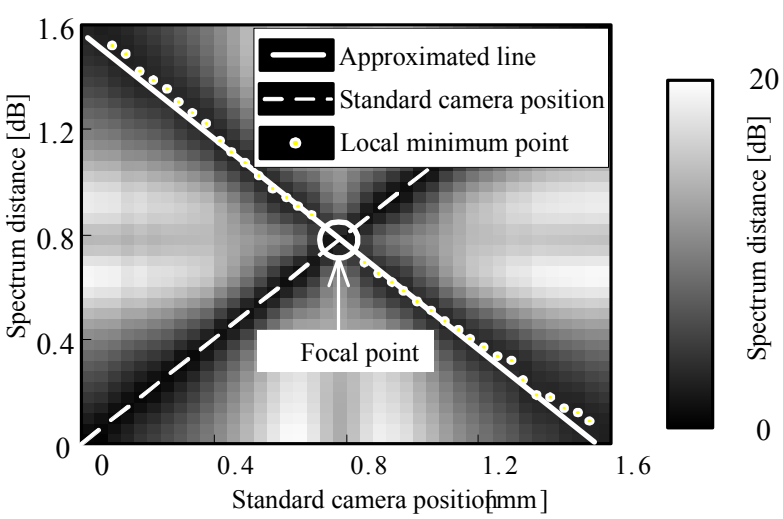

Fig. 8. Detection of focal point

〈4·3〉極小点の検出 基準となる画像（基準カメラ 位置）を固定し，(5)式により他の全ての画像との距離を求 める。得られた距離に対し，ある閾值（最大距離と最小距 離を二分する距離）を設け，閾值以下となる領域を求める (Fig. 7)。領域が二つであれば，各領域内の極小点を求める。 この二つの極小点は(4)式の二つの解に相当する。初期の閾 值で領域が一つであった場合, 最大距離と最小距離の四分 点，八分点で同様の処理を行い，二つの極小点を求める。

〈4-4〉 合焦位置検出 基準カメラ位置と異なる極小 点位置を最小二乗法により直線近似し，比較カメラ位置と 基準カメラ位置が等しくなる点を合焦点の位置とする。検 出の様子を Fig. 8 に示す。

\section{5. 周波数比較法の妥当性検証}

予備実験として, カメラを傾けず, カメラを $\mathrm{z}$ 方向に移動 させた場合での周波数比較法の精度を検証する。実験で用 いた画像を Fig. 9 に示す。

カメラの初期位置を $0.00[\mathrm{~mm}]$ から $0.50[\mathrm{~mm}]$ まで 0.10 $[\mathrm{mm}]$ 刻みで移動させて計測する。カメラの初期位置と合焦 位置の関係を，傾き 1 の直線に最小二乗法で直線近似した。 この近似直線と計測点との差 $\Delta e_{i}$ の標準偏差を誤差 $e$ とする。

$$
e=\sqrt{\frac{1}{N-1} \sum_{i=0}^{N-1} \Delta e_{i}^{2}}
$$

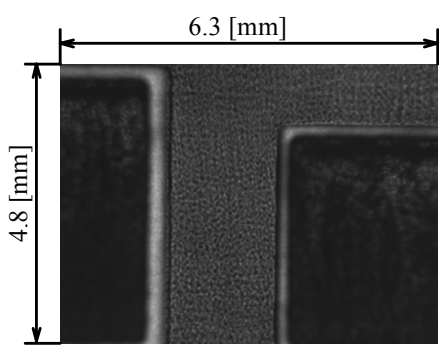

(a) Image Size

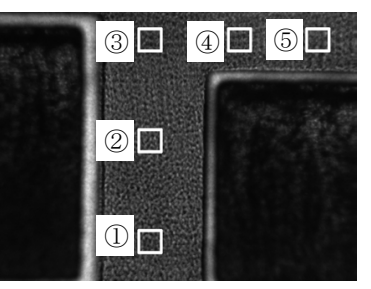

(b) Evaluated spot
Fig. 9. Sample image

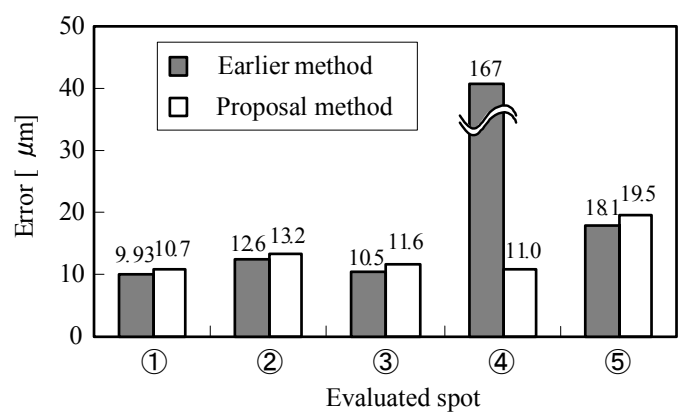

Fig. 10. Error comparison at each spot

ここで， $N$ は計測数である。標準偏差が小さいほど計測 のばらつきが少なく，精度が高いとする。

局所領域サイズ $64 \times 64$ [pixel] における変形ラプラシア ンによる高さ計測 (従来法) と従来法の誤差を Fig. 10 に示す。

変形ラプラシアンを用いた従来法では, 合焦評価值が最 大となる $z$ 位置と, その前後の $z$ 位置での合焦評価值を元 に，二次関数近似により合焦位置を求めている。しかし， 被写界深度と同程度以下のピッチで $z$ を動かす場合, 合焦 位置付近での評価值の変化が少ない。評価值が最大值とな る $z$ 位置も変化する場合があり, その場合には大きな計測 誤差が生じることとなる。この現象が計測点(4)で生じたた め，計測点(4)のエラーは非常に大きくなっている。

一方, 周波数比較法では, 計測点(4)以外のすべての計測 点において, 従来法と同等の精度が得られることに加え, 誤差が大きい計測点(4)についても, 周波数比較法では誤差 が $20[\mu \mathrm{m}]$ 以下の精度で安定して計測できた。

さらに，撮影間隔による精度への影響を調べる。画像枚 数を削減することにより擬似的に撮影間隔を変えて計測し た。このときの誤差を Fig. 11 に示す。

従来法では撮影間隔が広くなる場合, 誤差が大きくなる 傾向となった。それに対し，提案法では撮影間隔が変化し ても精度がほとんど変わらないことが確認できた。撮影間 隔が最大の場所では提案法が従来法より 10 倍以上の精度で 計測できる。提案法は, 撮影間隔の影響を受けにくいと言 える。撮影間隔を変えたときの合焦位置検出の様子を Fig.12 に示す。各凡例は Fig. 8 に従う。画像枚数を削減したときで も極小点位置の線形性が保たれており, 交点検出に不都合 な点は見られない。従来法では少数の点（3 点）から二次曲 線近似により合焦位置を求めており, 撮影間隔と同程度の 


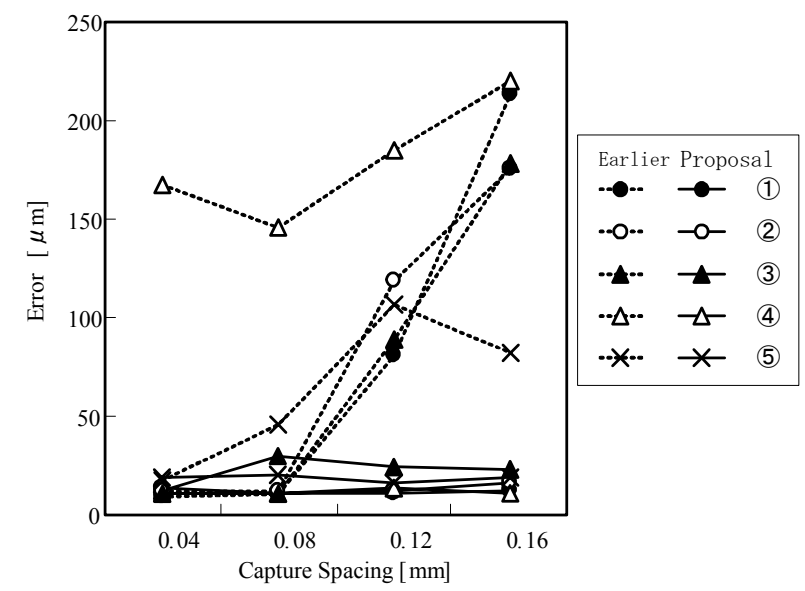

Fig. 11. Error on various spacing

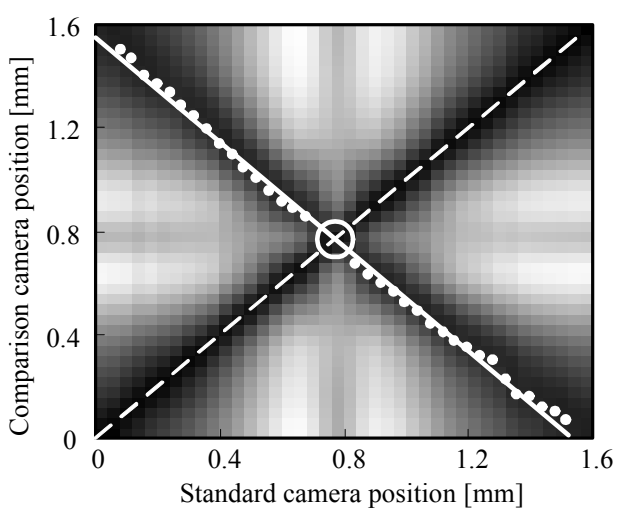

(a) Capture spacing $=0.04[\mathrm{~mm}]$

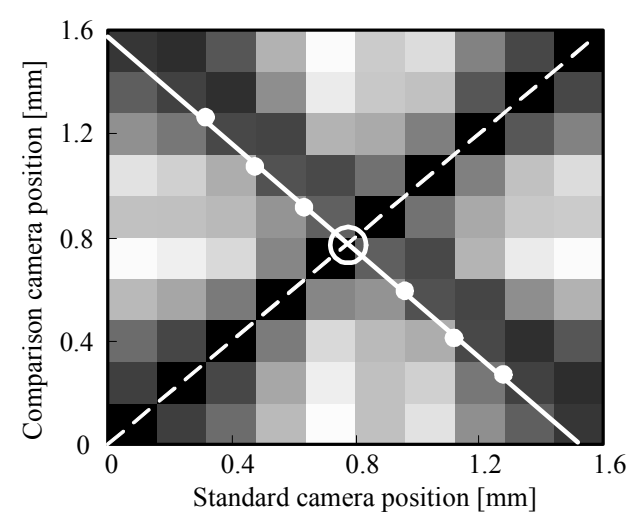

(b) Capture spacing $=0.16[\mathrm{~mm}]$

Fig. 12. Detection of focal point on different spacing

オーダーの誤差が生じていると考えられる。しかし，提案 法は合焦付近以外の複数の極小点を利用しており，合焦位 置の精度は極小点の精度と個数に影響する。本実験におけ る画像枚数の範囲では十分な数の極小点を検出できるた め, 画像枚数を削減しても精度が保たれると考えられる。

\section{6. 区分的焦点画像での評価}

評価に用いた領域を Fig.13 に示す。局所領域サイズを 32 $\times 32$ [pixel] とし, 局所領域内では材質の変化がない領域を 選択している。区分的焦点画像では局所領域の位置は画像

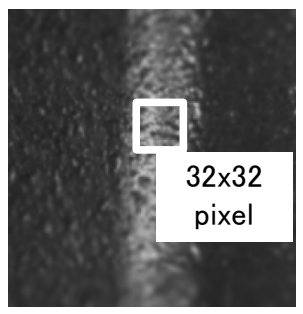

Fig. 13. Evaluated spot

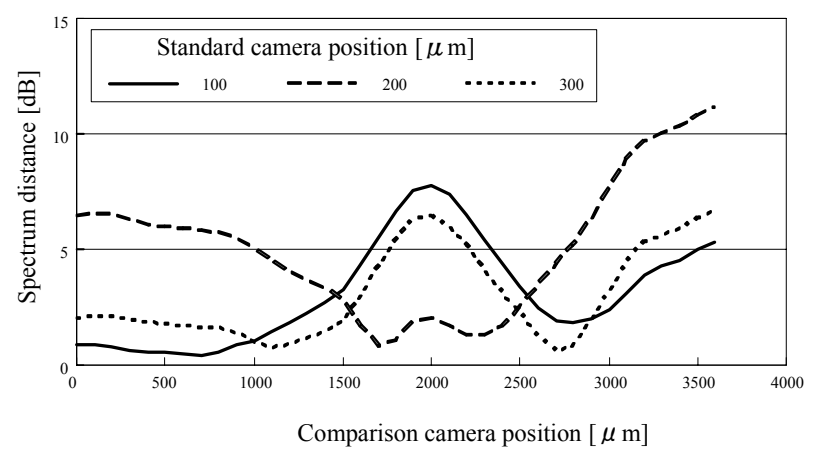

Fig. 14. Frequency distance at various standard position

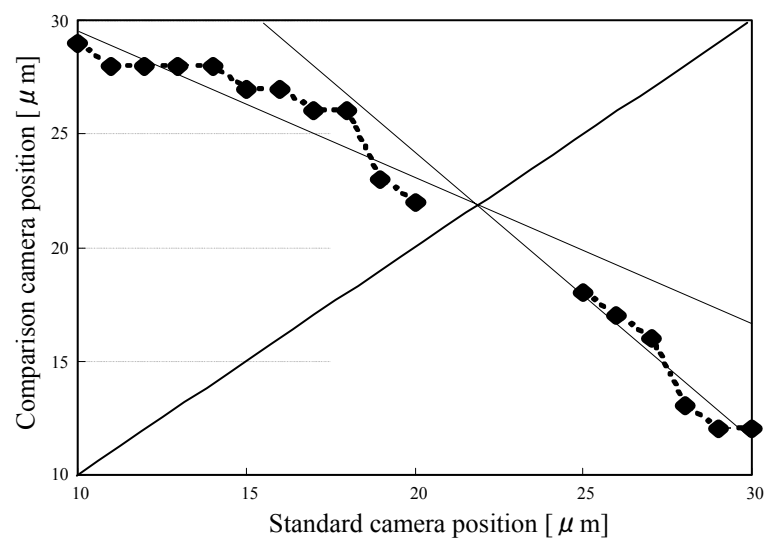

Fig. 15. Detection of focal point using segmental focal images

中で常に移動するため, 画像より得られた平均的な移動量 を元に, 局所領域の位置を調整している。得られた局所領 域は真值に対して最大 2 [pixel] のずれが存在する結果であ った。上記のずれ幅であれば, 同様なテクスチャのみが存 在する領域が抽出できるため, 周波数比較法の妥当性を検 証するには十分であると考える。

この領域に対して周波数比較を行った結果を Fig. 14 に示 す。予備実験と同様に，二つの極小值が存在していること がわかる。しかしながら, 合焦点位置より手前側では $z$ の 変化に対して周波数距離の変化が少なくなっている。距離 の変化が少ない場合，ノイズに対するロバスト性が低下寸 るため原因を分析していく必要がある。

次に, 合焦位置検出時の結果を Fig. 15 に示す。前項の周 波数比較法による合焦検出が可能なプロファイルではある が, 合焦位置の前後で直線性が変化しており, ぼけ方に非 対照性があると考えられる。 $z$ の変化により, 空間スケー 
ルの変化も含め, 今後, 精度向上を行ううえでぼけの非対 称性を含めてモデルを修正していく必要がある。

\section{7. 結 び}

合焦法による三次元計測を高速化するため，二つの手法 を組み合わせた手法の検討をおこなった。

まず，基準面に対してカメラ光軸を傾けることで一枚の 画像中で複数の焦点情報を持った区分的焦点画像を撮影す る方式の開発／テストを行った。上記光学系で，撮影対象 を平行移動させ，視野の移動と異なる焦点情報での撮影の 両立を行った。この手法では，追加の機構は必要なく，一 定速度での一軸移動のみで三次元計測が可能となるため, システムの簡素化及び計測の高速化が可能となる。

次に周波数比較法による計測の妥当性を検証した。細か い撮影間隔での撮影では，従来の手法と同程度の精度を達 成することができた。さらに周波数比較法では，ぼけ画像 同士の比較を行うため，合焦位置近傍の撮影は不要であり， 画像枚数を削減して計測した場合でも，誤差の増加が抑え られる。

周波数比較法は従来法と比べて周波数全体を比較してお り，フーリエ変換の処理も必要なため，処理時間は増加す る。しかし，これまでの計算機の高速化を考えれば，計算 時間よりも撮影時間の方が問題であり，画像枚数を削減で きることは大きな利点である。さらに，学習などの処理を 用いていないため, 従来の計測器の焦点検出アルゴリズム の変更だけで適応可能であり，撮影環境を変えず検査装置 の精度を高めることが可能である。

区分的焦点画像の撮影と周波数比較法を併用したシステ ムの検討を行った。周波数距離で 2 つ極小值が存在するこ とや，対応するぼけの位置変化等において，通常の光学系 での周波数比較法と同様の傾向を得ることができた。しか しながら，極小值付近での距離変化が少ない，合焦位置に 対して前側／後側で，ぼけの非対称性が存在することがわ かった。

今後, ぼけの非対称性等も加味し, より高精度なシステ ムを構築するとともに，テクスチャ変化のあるエッジ領域 での計測にも対応していくことが課題である。

(平成 21 年 11 月 18 日受付，平成 22 年 4 月 10 日再受付)

\section{文献}

（1）井口征士・佐藤宏介：「三次元計測」，昭晃堂 (1990)

（2）山下 淳・樋口裕和 ・金子 透:「光切断法による水中物体の 3 次元 計測」, 精密工学会誌, Vol.73, No.2, pp.265-269 (2007)

（3）服部数幸・佐藤幸男:「スキャン式符号化法による小型高速レンジフ アインダ」, 信学論, Vol.J76-D-2, No.8, pp.1528-1535 (1993)

（4）佐藤宏介・井口征士：「液晶レンジファインダ一液晶シャッタによる 高速距離画像計測システムー」, 信学論, Vol.J71-D-7, pp.1249-1257 (1988)

(5) S. Nayar : "Shape from Focus", IEEE Trans. Pattern Analysis and Machine Intelligence, Vol.16, No.8, pp.824 -831 (1994)

(6) M. Nigochi and S. K. Nayar : "Microscopic Shape from Foucus Using Active Illumination”, Proc. Of Int. Conf. On Pat. Recog., pp.147-152 (1994)
（7）石原満宏：「合焦法による高速三次元計測」, 精密工学会誌, Vol.63, No.1, pp.124 (1997)

(8) M. Subbarao and G. Surya : "Depth from Defocus : A Spatial Domain Approach", International Journal of Computer Vision, Vol.13, No.3, pp.271-294 (1994)

（9）杉浦彰彦・相澤清晴・原島 博：「焦点ボケ量推定を用いた単一画像 の距離測定方式」, 信学論, Vol.J81-A-4, pp.518-526 (1998)

(10) E. Krotkov : "Focusing", Int. J. Computer Vision, Vol.1, No.3, pp.223-237 (1987)

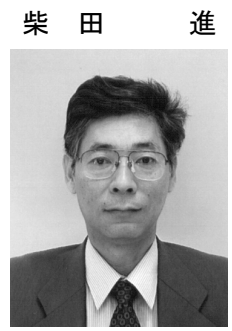

（非会員）1982 年同志社大学卒業。現在画像に よる非接触 3 次元計測システム開発に従事。

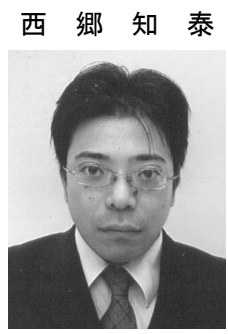

（非会員） 2000 年京都大学理学部数学科卒業。 2002 年京都大学大学院エネルギー科学研究科 修士課程修了。現在画像による非接触 3 次元計 測システム開発に従事。

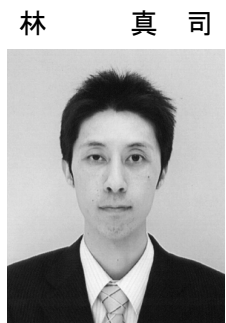

（非会員） 2006 年名古屋工業大学卒業。現在画 像による非接触 3 次元計測システム開発に従 事。

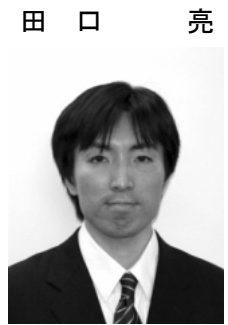

(非会員) 2002 年豊橋技術科学大学工学部知識 情報工学課程卒業。2004 年同大学大学院工学研 究科 知識情報工学専攻修了。2008 年同大学大 学院工学研究科 博士後期課程電子 - 情報工学専 攻修了。同年名古屋工業大学助教, 現在に到る。 博士 (工学)。ロボットとの対話や言語獲得に 関する研究に従事。人工知能学会, 情報処理学 会, 日本ロボット学会, 日本認知科学会各会員。

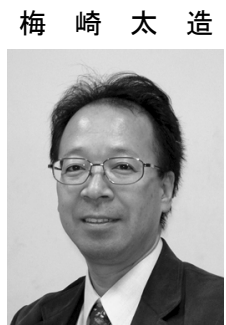

（正員）1982 年豊橋技科大 ·工・情報卒業。1987 年名大大学院博士課程修了。同年 4 月名大助手。 1990 年中部大講師。1992 年同大学助教授。1993 ～1994 年カーネギーメロン大学客員研究員。 1999 年中部大教授。2003 年名工大教授。工博。 音声・画像情報処理, 聴覚障害児教育, 福祉口 ボットの研究に従事。2003 年日本福祉工学会論 文賞，2006 年グッドデザイン賞，2008 年産学 官連携功労者表彰 科学技術政策担当大臣賞受賞。情報処理学会, 日本音響学会, 電子情報通信学会, 日本福祉工学会, ヒューマンイ ンターフェイス学会, 生体医工学会, 日本ロボット学会, 精密工学 会各会員。 